\title{
Climate change denial, freedom of speech and global justice
}

\author{
Trygve Lavik
}

Department of Philosophy, University of Bergen, Trygve.Lavik@uib.no

DOI: http://dx.doi.org/10.5324/eip.v10i2.1923

(cc) BY

This is an open access article distributed under the terms of the Creative Commons Attribution 4.0 International License, which permits unrestricted use, distribution, and reproduction in any medium, provided the original author and source are credited.

In this paper I claim that there are moral reasons for making climate denialism illegal. First I define climate denialism, and then I discuss its impact on society and its reception in the media. I build my philosophical arguments mainly on John Stuart Mill and Thomas M. Scanlon. According to Mill's utilitarian justification of free speech, even untrue opinions are valuable in society's pursuit of more truth. Consequently one might think that Mill's philosophy would justify climate denialists' right to free speech. A major section of the paper argues against that view. The main arguments are: Climate denialism is not beneficial because its main goal is to produce doubt, and not truth. Climate denialism is not sincerely meant, which is a necessary condition for Mill to accept utterances. Climate denialists bring harm, by blocking necessary action on climate change. Primarily they harm future generations and people in developing countries. Hence the case can be made in terms of global justice: Would future generations and people in developing countries support my claim? I think so, or so I argue. My argument from global justice is built on Scanlon's distinction between the interests of participants, the interests of audiences, and the interests of bystanders. The climate denialists have participant interests "in being able to call something to the attention of a wide audience". Audience interests consist of "having access to expressions that we wish to hear or read, and even in being exposed to some degree to expressions we have not chosen". Future generations and people in poor countries are bystanders to the climate debate. If the debate postpones necessary actions, it is the bystanders who must pay the price. I argue that bystanders' costs outweigh participants' and audiences' interests, and that this is an argument for a statutory ban on climate denialism.

Keywords: climate change denial, freedom of speech, global justice, utilitarianism, harm principle

\section{Introduction}

Imagine the following thought experiment:

The pharmaceutical industry has invented a medicine that eliminates morning sickness during pregnancy. ${ }^{1}$ The medicine has been tested, and there is no indication that the medicine will affect the baby. The babies that are born are normal. However, a scientist has begun to research whether this medicine may have 
potential long-term effects. Will these babies' lives be negatively affected as they grow up, or when they become adults? Let us assume that, according to other wellestablished medical research, there are good reasons to believe that these babies will suffer paralysis of the legs when they have grown up. Experiments with animals that reach maturity in one year also show that many of these animals suffer paralysis when they mature. The scientific society takes this very seriously, and establishes a panel that reviews all the research in the field. After reviewing all the science on the subject, the panel concludes that it is very likely that this medicine will have the very dangerous adverse effect described above. Furthermore, the academes of science in all the leading countries have approved the scientific reasoning and support the conclusion of the panel. However, at the same time, the pharmaceutical industry launches a campaign to create doubt about the scientific conclusion that has been reached through research. They establish quasi-scientific institutes and hire acknowledged scientists to argue that the science is not settled at all. Moreover, they initiate a petition that completely denies that this medicine might have dangerous long-term effects. They pay a lot of scientists to sign the petition. The media want to be fair and balanced, so they present both sides of the issue. The result is that many women continue to take the medicine during pregnancy. Twenty years later, tragedy strikes. The legs of the children of the mothers who took this medicine during pregnancy become paralyzed. The question now is: is it reasonable to claim that someone has committed a crime against these children? And if so, is this not an argument for introducing a law prohibiting this kind of crime? I believe so, and in this paper I will argue that climate denialists commit a crime similar to that of the fictive pharmaceutical industry denialists in my thought experiment. ${ }^{2}$

The claim I will defend in this paper is that there are moral reasons for making climate denialism illegal. I shall first describe climate denialism and then discuss the impact of climate denialism and the role of media (sections 1-3). Then I shall discuss the usefulness and harm of climate denialism and then claim that climate denialism should be prohibited (sections 4-5). In the final section, I will discuss some problems with enacting a law against climate denialism (6).

\section{What is Climate Denialism?}

Fredrick Seitz is a former president of the US National Academy of Sciences (NAS). In 1998, Seitz wrote a document (later called the Oregon petition) in which he denied the central theses of man-made global warming. He deliberately printed it in the font and format of the Proceedings of the National Academy of Sciences, the journal of the NAS. The NAS council soon after released a statement saying that NAS had nothing to do with the document, and that the academy was worried about the confusion this document had caused. According to the petition's home page, 31,487 scientists have signed this petition. ${ }^{3}$ The Oregon petition was long ago exposed as a fraud. Most of the signers were not scientists at all, and many of them did not know that their names were on the list. Despite this, the Oregon petition is still very much alive (Monbiot 2006: 29-31). The Oregon petition is one example of the so-called "denial industry". This term, introduced by George Monbiot, describes the well-organized and well-funded campaign by a handful of scientists, free-market think tanks and industry to produce doubt about climate change (Monbiot 2006: 20-42). Denial campaigns against science did not occur for the first time with the 
theory of global warming. In the book Merchants of Doubt (2010), Naomi Oreskes and Erik Conway demonstrate how a handful of scientists have obscured the truth on issues like tobacco smoke, acid rain, ozone holes, second-hand smoke and global warming. The story they tell is about a small group of scientists, who in collaboration with right wing think tanks and industry, have run a successful campaign to mislead the public about science.

Many would probably say that this small group of scientists do us all a favour. Scepticism is a good thing in science, and in public debate. A sceptic is a person who does not accept truths just because an authority or a majority believes so: he wants to hear all the arguments. However, he is no longer a sceptic if he does not respect the force of the better arguments. In this paper, I will argue that while sound scepticism is a good thing in science and public debate, denialism is not, and there is a big difference between scepticism and denialism.

So how is it possible to distinguish between scepticism and denialism? I propose that the distinction can be made with the help of the concept of "good faith". To be in good faith means to be sincere. But how can we know whether someone is sincere or not? We cannot look in to other people's minds. To answer this question it is instructive to consider how good faith is treated in law. In law, good faith does not mean what you actually think or what you claim to know and not know. It means what you under certain circumstances should know. If you for example buy jewellery from a drug addict on the street, you might claim that you acted in good faith, and perhaps you also did not know better, but under such circumstances you should have known better. You are not acting in good faith. To make this point clearer I will also bring in another concept from law, namely the principle of "caveat emptor": let the buyer beware. For example, when you buy a flat you have a duty to investigate the property for sale. Let us say a man named Bob buys a flat. After Bob has lived there for some weeks he discovers mould in a wall. Bob complains to the salesman and asks for a price reduction. The salesman refuses to pay, and Bob takes the case to court. In court Bob claims that he acted in good faith when buying the flat. He really believed that it was a flat without defects. Bob loses the case, because he should have inspected the flat and thus known that the flat had a defect.

The distinction between being in good faith and not being in good faith is useful to explain the difference between a sceptic and a denier. A sceptic acts in good faith, a denier does not. If a denier claims that climate scientists do not take sun activity in to consideration, he is not in good faith. He should have investigated what climate scientists say about the subject first. My distinction between scepticism versus denialism reflects a central definition of climate denialism. Michael Shermer argues that denial is the "automatic gainsaying of a claim regardless of the evidence for it" and that "denialism is typically driven by ideology and religious belief" (Shermer 2010: 36). Shermer is of the opinion that the so-called climate sceptics are mostly deniers, and not sceptics at all, because scepticism entails taking a scientific approach to the evaluation of claims. Washington and Cook say that: “...refusing to accept the overwhelming "preponderance of evidence" is not scepticism; it is denial and should be called by its true name" (Washington \& Cook 2011: 2). Stefan Rahmastorf has devised a typology of climate sceptics that has been adopted by many commentators. He distinguishes between three levels:

1. Trend sceptics: those who deny the warming trend; 
2. Attribution sceptics: those who accept the trend and attribute it to natural causes;

3. Impact sceptics: those who accept human causation of the warming trend but claim that the impacts will be beneficial or benign (Washington \& Cook 2011: 11).

Although it is impossible to predict the precise impact of global warming, the "predictions in broad terms are clear" (Broome 2012: 31), and there is no doubt that climate change will harm millions of people. This typology can be combined with the distinction between climate sceptics and climate deniers. Let us imagine a dinner party comprising four climate scientists, and four climate sceptics. First, they discuss whether there is a warming trend or not. After a while, three of the sceptics recognize the better arguments, and accept that the planet is getting warmer. The fourth sceptic refuses to give up his position, even though he no longer has any arguments. Then the party goes on to discuss whether this warming trend is human induced or not. After a while, two of the sceptics recognize the better arguments. The third sceptic refuses to give up his position, even though all the arguments prove him to be wrong. The same story repeats itself when they discuss the impact of man-made climate change. At the end of the party, only one of the initial "sceptics" is still a sceptic, the three others have proved themselves to be deniers.

This dinner party is an analogy to the climate debate in the public. And the denial industry can be compared with the three deniers at the party. None of these deniers are acting in good faith, they are not sincere. The fact that the activities of the denial industry are dishonest is well documented. The strategy used by climate deniers is very much like the one used by the tobacco deniers. Many of the same people who were engaged in the denial of tobacco are also involved in the denial of climate change (Oreskes \& Conway 2010, Monbiot 2006: 31). No one has formulated this strategy better than they have themselves: "Doubt is our product", proclaimed an internal tobacco industry document in 1969. "Spread doubt over strong scientific evidence and the public won't know what to believe" (Saloojee \& Dagli 2000: 9003).

When proposing a ban on climate denialism, it is necessary to distinguish illegal climate denialism from legal climate denialism. In this paper, "illegal climate denialism" will mean "a well-organized and well-funded campaign by a person or group with authority in society, which keeps repeating the same untrue and damaging claims about climate change, without mentioning conclusive counter arguments". The Oregon petition, and its legacy, is a clear example of climate denialism that can be subsumed under this definition. I will also give another example: The Hartland Institute is a right-wing think tank and lobby group that receives massive financial support from Exxon Mobil. In 2007, the Hartland Institute published a list of 500 scientists who were said to deny human-induced climate change. Shortly afterwards, many of the scientists declared that they had been falsely cited, and they demanded that their names be taken off the list immediately. By 2009 none of the names had been removed from the document (Monbiot 2009). Finally, the so-called "climate gate" campaign is another example that clearly can be subsumed as illegal climate denialism. However, some phenomena should not be considered illegal, such as a climate scientist who publishes peer-reviewed articles that deny man-made climate change, and a layman 
who writes climate denial opinion pieces in newspapers, or participates in the climate denial blogosphere, and so on.

\section{Is the denial industry a reason for inaction on the climate problem?}

George Monbiot (a recognized environmentalist and author) writes that "the professional denial industry has delayed effective global action on climate change by several years (Monbiot 2006: 39). ${ }^{4}$ Philosopher Philip Kitcher thinks that "climate deniers have successfully blocked attempts to introduce policies for coping with potential environmental change"(Kitcher 2011: 243). I take it that Monbiot and Kitcher implicitly reason as follows: the denial industry spreads misinformation through newspapers, radio and television. This misinformation deceives a major portion of the public. Hence, the majority do not think that climate change is a big problem. And the result is that people do not put pressure on governments to act. However, there are many objections to this line of reasoning. I will address three of them:

a) There is not much climate denialism among people;

b) The lack of political action causes apathy in the public;

c) There is no causal link from climate denialism in the media to climate denialism among people.

a) There is not much climate denialism among people:

TNS Gallup has recently conducted a survey on climate change notions in Norway. Among "major challenges facing Norway" people rank climate change number six, behind health care, schools and education, immigration and integration, expanding roads and railroads, and increasing violence and crime (TNS Gallup 2011).

In the same survey, people were asked whether they had confidence in the conclusions of the IPCC. The results were

\begin{tabular}{ll}
\hline Very high trust & $8 \%$ \\
High trust & $26 \%$ \\
Some trust & $41 \%$ \\
Low trust & $12 \%$ \\
Very low trust & $7 \%$ \\
Don't know & $7 \%$ \\
\hline
\end{tabular}

Table 1: TNS Gallup 2011

Only one-third of the respondents had very high/high confidence in the conclusions. In the survey, $41 \%$ said they thought that the IPCC is influenced by politics, while $33 \%$ held that the IPCC is independent. The rest (26\%) said they "don't know". The survey also showed a decline in the belief that climate change is man-made. In the autumn of $2009,74 \%$ totally/partially agreed that climate change is human-induced, while in the autumn of 2011, $65 \%$ said that they totally/partially agreed that climate change was man-made. This may seem like a high score. However, many of the $65 \%$ just partially agree. A survey conducted by YouGov showed that almost half of the Norwegian population believe that the climate 
problem is exaggerated (NRK 2010). Moreover, in another recent survey $42 \%$ of the respondents totally/partially agreed that "Climate change is only natural variation in the temperature of the Earth" (Andersson 2012 in Bergens Tidene). ${ }^{5}$ Conclusion: there is increasing climate denialism among people. ${ }^{6}$

b) The lack of political action causes apathy in the public:

Another objection is that climate deniers are not those who cause apathy in the public; instead, it is the lack of political action. The argument goes: the public see that politicians are not trying to solve the problem. They therefore think that politicians do not believe global warming is a big problem. The conclusion drawn (by a large part of the public) from all this is that climate change is not a big problem.

There are several problems with this explanation. One premise is that people regard their politicians as the most important authorities on questions concerning what to believe about the world: for example, that a politician is more authoritative on scientific issues than a scientist. Another problem arises if we try to turn this explanation into a deductive-nomological model of explanation:

L If the public perceive that their leaders are not trying to solve an assumed problem $\mathrm{X}$, the public will tend to believe that $\mathrm{X}$ is not a serious problem.

C Their leaders do not make any effort to solve the problem $\mathrm{X}$.

$\mathrm{E}$ The public do not believe that $\mathrm{X}$ is a serious problem.

Let us then replace "X" with "health care", "crime", "immigration" or "roads". It is then apparent that this explanation cannot be generally valid. Thus, it can hardly explain the widespread belief that the climate change problem is being exaggerated. One could argue that in matters like health care, crime, immigration and roads, people see and experience the problems themselves, for example when they watch the evening news, or drive over a bump in the road. So if the politicians do not act, they still know that the problems remain unsolved. The problem with this objection is that it introduces another argument: the reason why people do not believe in climate change is because they cannot see or experience the problem first-hand. But this explanation is quite different from that which explains disbelief as a result of a perceived lack of political action.

c) There is no causal link from climate denialism in the media to climate denialism among people: ${ }^{7}$

A major problem in recognizing climate change as a big problem is that people cannot directly experience it. This explanation, which is almost self-evident, is based on human psychology. Human psychology is probably the most important source of climate denialism. Short-term thinking, self-deception, and the unwillingness to sacrifice achieved goods are all human vices. Many people would most probably have become climate deniers even without the denial industry. However, it does not follow that the denial industry has no impact. These human vices provide fertile ground for promoting climate denialism. The fact that there is fertile ground for denial among people is not a strong case for claiming that the denial industry does not have any effect on people's thinking. That would be similar to saying that advertising agencies do not have any impact merely because there is already demand for the products (for example, face moisturizer) in the market. The denial industry spends millions of dollars to produce and spread climate scepticism. They would be 
wasting their money if there was no connection between climate denialism in the media and public opinion. A lot of sociological research has been done on this subject, and Dunlap and McCright are crystal clear about what their findings tell them:

The climate change denial campaign has been successful. Organized and well-funded denial efforts have convinced many policy-members and citizens that the scientific evidence for human caused atmospheric warming remains so uncertain that regulating carbon emissions is not urgent (Dunlap \& McCright, 2013: 2).

Conclusion: the denial industry is a reason for inaction on the climate problem. However, the denial industry could not have achieved this without help from the media.

\section{Climate change denial and the media}

There are at least three factors that shape how the climate problem is portrayed in the media: ${ }^{8}$

1) Political dependency;

2) Commercial dependency;

3) The journalistic norm of balance.

It is obvious that certain media institutions, such as the Fox News channel, are not independent of political interests in their coverage of climate change (Dimiero 2010). The media are not independent of commercial forces, since media institutions need readers, listeners and viewers. If a debate on climate change on television presents ten climate scientists, all of whom agree that climate change is real, human-induced, and impels us to change our lifestyles, the show will probably get bad ratings. A debate between one climate scientist who claims that climate change is human-induced and one denier who argues that there is no climate change at all is more likely to attract an attentive audience. I believe it is noncontroversial to be critical of the media's dependency on political and commercial interests. ${ }^{9}$ The topic for this paper, however, is to demonstrate how climate denialism is supported by our idealistic norms of free speech, as echoed in the journalistic norm of balance.

Balance demands that all perspectives on a controversial issue be illuminated. Obviously, the climate deniers benefit from the ethics of journalism. Ross Gelbspan has given a good analysis of the situation:

The professional canon of journalistic fairness requires reporters who write about a controversy to present competing points of view. When the issue is of a political or social nature, fairness-presenting the most compelling arguments of both sides with equal weight-is a fundamental check on biased reporting. But this canon causes problems when it is applied to issues of science. It seems to demand that journalists present competing points of views on a scientific question as though they had equal scientific weight, when actually they do not (Gelbspan 1998: 57-58). 
There is nothing wrong with the norm of balance in media, but the way this norm has been applied in the coverage of climate change is highly questionable. Julius and Maxwell Boykoff studied the media coverage of climate change in the USA between 1988-2004. They found that 53\% of the coverage was "balanced", that is, it gave equal time to the majority view of science and climate scepticism. This balanced coverage was named "balance as bias" by Boykoff \& Boykoff (2004).

The journalistic norm of balance is rooted in the values of free speech, which most of us consider vital for the well-being of a democratic society. The common view is, as I have said, that free discussion is always a good thing. In the next two sections I challenge that view.

\section{Is climate change denial useful in society?}

An editorial in The Independent states that:

The climate change sceptics have done us all a favour (...) by challenging the consensus view of global warming, the sceptics have tested the flabbier assumptions of that consensus and forced the proponents of the majority view to sharpen their arguments (7 February 2010 as cited in Painter 2011: 45).

This editorial echoes the values of free speech. Free discussion is always a good thing, a view that is shared by a majority in democratic countries. However, there are some exceptions. In his recent book, Science in a Democratic Society, Philip Kitcher contends that:

When the conditions of public discussion with respect to important and central issues allow for, even foster, widespread states of irremediable ignorance (as well as resistance and alienation), asserting the value of "free exchange of ideas" is no more than the expression of a shallow, habitual piety (Kitcher 2011: 182).

In stark opposition to the moral in the editorial in the Independent, Kitcher claims that: "As things stand, 'free and open public discussion', far from being the expression of democratic values, is actually subversive" (Kitcher 2011: 185).

In On Liberty, Mill makes a strong case for freedom of thought and expression. Apparently, the editorial in the Independent is more in line with Mill's philosophy than with Kitcher's disillusioned remarks. I shall now argue the opposite.

Mill defends free speech as the best means for producing more truth; it is declared useful because he thinks it increases the sum of justified beliefs. ${ }^{10}$ I claim that the opposite is the case in the current climate debate, so my argument is a Millian, utilitarian one. Against this one might argue: Mill claims that silencing an untrue utterance is like robbing from mankind the possibility to challenge, reconsider, and perhaps reaffirm our true views. On the other hand, Mill claims that, although we should allow utterances even though they may turn out to be false, we should only accept utterances that are sincerely meant. I have argued above that there is good reason to doubt the sincerity of the denial industry. Even when argumentation succeeds in refuting a climate denier's claim, climate denialists do not respect "the unforced force of the better argument". Climate change denialists merely reiterate their false claims whenever the chance arises. The result of this activity for the public is not "clearer perception and livelier impressions of truth", 
but instead doubt and distrust. Moreover, Mill defines utility as "grounded on the permanent interests of a man as a progressive being" (Mill [1859] 2003: 81). This is not compatible with the nature of denialism, which has been defined as "the automatic gainsaying of a claim regardless of the evidence for it"(Shermer 2010: 36).

So it is not unquestionable that Mill would have embraced the denial industry's right to free speech. However, there are also other aspects of modern debates over science that Mill could not have foreseen, and which challenge his utilitarian justification of free speech. The research group The Cultural Cognition Project, led by Dan Kahan, has published many studies on the relationship between values and risk perception. They have studied several public debates over controversial scientific matters. One result is that more public debate does not move the public towards a consensus in line with the scientific consensus (Kahan and others 2011). In a recent study, a team of researchers has demonstrated that it is not people's lack of scientific expertise that hinders them from understanding the scientific claims about climate change. The hindrance is people's values. In short: People with rightleaning values-or "hierarchal individualists" as they are called in the report-tend to be less worried about climate change than people with left-leaning values-or "egalitarian communitarians" (Kahan and others 2012). The problem is not the ability to comprehend science, but the willingness to accept information that contradicts our values. Another study points in the same direction. Andrew Binder and his research group have found that more discussion only amplifies initial perceptions of the debaters (Binder, Scheufele, Brossard \& Gunther 2011). In a news report on ScienceDaily, Binder is quoted saying:

Our results demonstrate very clearly that the more people talk about divisive science and technology issues, the less likely the two camps are to see the issue in the same way. This is problematic because it suggests that individuals are very selective in choosing their discussion partners and hearing only what they want to hear during discussions of controversial issues (North Carolina State University 2010).

These findings challenge Mill's utilitarian justification of the liberty principle. If free discussion does not work, if more debate does not lead to more truth, then free speech is not useful.

An objection to this argument is that, in the long run, truth will prevail through public debate. Society should not make exceptions for debates that do not seem useful. Mill's justification of free speech is rule-utilitarian in spirit. It is the rule of free speech per se that is useful, not necessarily the outcome of one single debate. Making exceptions would weaken the rule as such. In other words: Even if there are many useless debates, most would in the long run lead to more truth. Hence, just because a debate is not useful to society is not a sufficient reason to ban it. The fact is that climate denialism is not scepticism but denialism is not by itself a sufficient reason to ban it. There are many other forms of denial in the public, like evolutional denial, 9/11 denial and tobacco denial (Shermer 2010: 37) which should be acceptable in society. So why then ban climate denialism? The reason is simple: the climate crisis is not just a single political problem among many other problems. The potential of catastrophe as a result of global warming makes the climate crisis an exceptional problem in the history of mankind. The climate crisis calls for immediate action, so we cannot wait and see if public debate merges with scientific 
consensus. Climate change will bring harm to others at a scale unlike any other event in the human history. This is the topic of the next section.

\section{Climate change denialism and harm to others}

The harm principle is generally associated with John Stuart Mill. In the introduction to On Liberty Mill states:

...the only purpose for which power can be rightfully exercised over any member of a civilized community, against his will, is to prevent harm to others. His own good, either physical or moral, is not a sufficient warrant (Mill [1859] 2003: 80).

Expressions normally do not harm other people in the same way as acts do. Mill, however, makes an exception for certain kinds of speech acts:

An opinion that corn-dealers are starvers of the poor, or that private property is robbery, ought to be unmolested when simply circulated through the press, but may justly incur punishment when delivered orally to an excited mob assembled before the house of a corn-dealer, or when handed about among the same mob in the form of a placard (Mill [1859] 2003: 121).

Climate change denial views are normally "circulated through the press" (and other media), so there is no warrant in this passage to condemn climate deniers. Obviously Mill himself has no opinion on climate denialism. However, the exceptional nature of the climate crisis can be characterized more as a heated situation in which certain utterances may lead to massive harm to others, than as a civilized debate in the press over regular issues such as Darwinism, abortion rights and the death penalty. If the debate on climate change postpones necessary actions, contributors to the debate may bring harm to others by their utterances.

Mill does not clearly indicate where to draw the line on "harm". Hence, commentators have given different interpretations (see Turner 2014). In this paper "harm to others" will mean "injury to the vital interests of others" (Turner 2014: 300). With this in mind, I will now argue against climate denialism based on global justice. Global justice involves the relationship between rich and poor countries in the world, not only today, but also from the perspective of future generations. The rich countries' emissions of greenhouse gases do injustice to poor countries and near future generations. ${ }^{11}$ If climate denialism blocks necessary actions to reduce the emissions, then it is not fair to allow climate deniers the right to spread their message, or so I shall argue.

In the beginning of this paper, I presented a thought experiment based on a fictive pharmaceutical industry. I will now argue from analogy as follows: since there should have been a law prohibiting the denialist campaign for this fictitious medicine, there should be a law against climate denialism. In elaborating my argument I will use T.M. Scanlon's distinction between the different interests of participants, audiences and bystanders.

Participants have interests "in being able to call something to the attention of a wide audience" (Scanlon 2003a: 86). Audience interests consist in "having access to expressions that we wish to hear or read, and even in being exposed to some degree to expressions we have not chosen" (Scanlon 2003b: 155). Bystander interests 
concern "changes in the audience's subsequent behaviour" promoted by expressions (Scanlon 2003a: 92). In my thought experiment above it is clear that participants, the pharmaceutical industry and the institutes and scientists working for them have an interest in being able to call something to the attention of a wide audience. A law banning their views on the research would suppress their autonomy. Moreover, such a law would damage the autonomy of the audience. Pregnant women are an important part of the audience. They have an interest in "having a good environment for the formation of one's beliefs and desires"(Scanlon 2003a: 91). A necessary condition for autonomy is that the audience can hear all sides of a case. If we assume the audience is mature, the state, as Mill said, has no right to regulate their freedom for their own good. So if they form the wrong beliefs and make the wrong decisions, that is not a sufficient condition for imposing restrictions on what they might be allowed to hear and read.

The significant bystanders are the children with paralyzed legs. They have paid a high price because of the activity of the denial industry. From their perspective, the right of the "freedom of exchange of ideas" with respect to this medicine would probably be an insult. They were the ones who had to pay the price. I assume that it is quite obvious that bystander interests outweigh participant interests and audience interest. Hence a law against the denial campaign is justified, and the same argument can be made for climate denialism.

Climate deniers have a participant interest in bringing their views to the table, as proponents for the opposite side of the issue. The audience for the debate is mostly people living in developed countries, and especially in the Anglo-Saxon world. The audience has an interest in "having a good environment for one's own beliefs and desires", so hearing both sides of the debate is a good thing from the audience's perspective. The bystanders are people living in developing countries and future generations. Although this is a rough and broad generalization, by and large this special debate about whether humans contribute to climate change or not is not much debated in developing countries (Painter 2011; Greenpeace 2013). ${ }^{12}$ By future generations I mean generations in the near future (children who are already born, and children who will be born in the next 50 years). ${ }^{13}$

If it is obvious that the bystander's interests outweigh the participant and audience interests in the thought experiment above, why should they not also outweigh participant and audience interests in the climate debate? People in developing countries and future generations will certainly be harmed by climate change. Is it reasonable to believe that they would have embraced the denial industry's right to freedom of speech? I believe not. The bystanders will be hurt by the change in audience behaviour due to the widespread influence of climate denialism; therefore they would have had strong moral reasons for prohibiting climate denialism.

Conclusion: In the last two sections I have argued that climate denialism is useless and further, that it will bring massive harm to others. However, I have not yet conclusively argued that the best solution to the problem is to ban climate denialism. This is the topic for the final section. 


\section{Climate denialism and the law}

Fredrick Schauer denies that it is possible to defend free speech as a means to an end, for instance that free speech leads to more truth. He argues that the only reason to allow free speech is that the alternative is worse: "the very idea of a principle of freedom of speech is an embodiment of a risk-averse distrust of decisionmakers" (Schauer 1989: 2) Catriona McKinnon interprets Schauer's point to be a slipperyslope argument. ${ }^{14}$ McKinnon discusses a possible ban of Salman Rushdie's novel The Satanic Verses. She claims:

Even if it is true that The Satanic Verses presents a wholly false and epistemically trivial picture of Islam, that inhibits human progress (...) to permit the state to make these judgements with a view to legislation is the first step on a slippery slope the end of which is a nightmarish Orwellian polity (McKinnon 2006: 129).

McKinnon makes the same point when she discusses Holocaust denial. ${ }^{15}$ It is illegal to deny the existence of the Holocaust in Austria, Belgium, France, Germany, Israel, Spain and Switzerland (McKinnon 2006: 160). Although it is illegal to deny the Holocaust in these countries, none of them has turned out to become "nightmarish Orwellian polities". This example shows that it is possible to restrict free speech on certain subjects without the slippery slope effect.

Schauer argues that freedom of speech is justified by our "distrust of decisionmakers". A law against Holocaust denial is unthinkable in the US, where the First Amendment has very strong protection. There are more restrictions in Europe, not only against Holocaust denial, but also in laws against political commercials on television. Despite this, nothing indicates that the public is less informed in these European countries than in the US, rather it is the opposite. It is more common in the US to disbelieve climate science, and other kinds of science as well. Hence, imposing some government restrictions on free speech does not necessarily ruin the public debate and cause citizens to be less informed.

Laws against Holocaust denial do not bring us to an Orwellian nightmare, so there is not much reason to fear that the same will happen if we enact a law against climate denialism. Furthermore, there are better reasons to outlaw climate denialism than Holocaust denialism. Holocaust denials are harmful to the surviving family members in particular, and are damaging to human dignity in general. The big difference between Holocaust denial and climate denial is that the former is a crime against previous and present generations, while climate denialism is a crime against present and future generations. If the widespread practice of climate denialism prevents actions to stop the burning of fossil fuels, the result will be runaway climate change that will kill tens of millions. In other words, climate denialism may kill people in the future, in a way that Holocaust denial, of course, cannot. Hence, climate denialism brings more massive harm into the world than Holocaust denialism.

One possible objection to my argument goes as follows: it is absurd to criminalize climate denial if governments simultaneously continue to allow it to be legal to burn fossil fuels. It would be similar to making it illegal to deny that all men are created equal, while allowing slavery to remain legal. ${ }^{16}$ My response to this objection is that although we do not have a law against the burning of fossil fuels, it is not necessarily absurd to introduce a law against climate denialism. Many countries have laws forbidding tobacco and alcohol advertising, while it remains legal to sell and 
consume these products. Hence, if we do not think that laws against cigarette and alcohol advertising are absurd, it is not more absurd to introduce a law against climate denial without making the burning of fossil fuels illegal.

My opponents might still argue: why is it not better to argue simply that there should be a law against the burning of fossil fuels? My response is that this proposal is for the future, and it is possible to decide a year for such a law, for example 2030. It is not possible to ban fossil fuels overnight because it would result in total economic breakdown. Fossil fuels have to be phased out. However, to be willing to phase out fossil fuels, we have to be prepared to take political action, which will be difficult unless most of the population believes that climate change is humaninduced, and consequently accepts that we should do something about it. So a law against climate denialism will not break down the economy, and combating climate denialism is one of many measures to move public opinion in the right direction. Public opinion is the key to solving the climate problem. If the public does not put pressure on politicians to act, not much will happen. So it is reasonable to argue in favour of outlawing climate denialism, without at the same time introducing a law against selling and consuming fossil fuels.

\section{Notes}

${ }^{1}$ This thought experiment is inspired by the Thalidomide scandal of the late 1950s, however this thought experiment differs in many ways from the real episode.

${ }^{2}$ This claim might seem very harsh, however, I will modify it in next section were I define climate denialism, and make a distinction between climate denialism and climate skepticism.

${ }^{3}$ http://www.petitionproject.org/

${ }^{4}$ See also Dunlap and McCright 2011: 156

${ }^{5}$ The survey was made by SIFO (The National Institute of Consumer Research) (Austgulen \& Stø 2012).

${ }^{6}$ Here I have only referred to surveys from Norway, but there are similar reports also from the EU and the USA.

7 In the comparative study Poles Apart (Painter 2011), James Painter and his research team report that climate sceptics get much more media attention in the UK and U.S. than in Brazil, China, France and India. But the report does not check whether there is a correlation between climate scepticism in the media and among the public. It is not established that giving climate sceptics much attention in the media leads to more climate scepticism in the public. Poles Apart cites a survey in Le Figaro where $70 \%$ of the respondents said they have doubts about the causes of global warming (Painter 2011: 78). This poll indicates that there is no correlation between the attention climate scepticism gets in the media and public opinion. However, to my knowledge the survey in Le Figaro was not a scientific investigation, so I suspect that the respondents are not representative of the public in France.

${ }^{8}$ In his recent book Who Speaks for the Climate?, Maxwell Boykoff mentions five journalistic norms that shape how climate change is presented in the media. These are "personalization", "dramatization", "novelty", "authority-order" and "balance" (Boykoff 2011: 99-120). I find it problematic that he does not distinguish between commercial and idealistic norms. Personalisation, dramatisation and novelty 
concern ways by which the media can attract the public, while balance reflects the democratic values of free speech.

9 As Jürgen Habermas comments: “A special case of damage to editorial independence occurs when private owners of a media empire develop political ambitions and use their property-based power for acquiring political influence" (Habermas 2006: 421).

${ }^{10}$ Someone might argue that they do not accept the utilitarian justification of free speech in the first place. They could argue: Freedom of speech is a basic right, and it does not matter whether it is useful or not. However, I shall not consider this objection in this paper.

${ }^{11}$ I use the term near future generations to avoid the non-identity problem (Parfit 2010). I do not consider generations far in the future.

${ }^{12}$ See chapter on "The Denial Machine Goes Global" (Greenpeace 2013: 26-31) http://www.climateaccess.org/sites/default/files/Greenpeace_Dealing in Doubt.pdf

${ }^{13}$ See endnote 8.

${ }^{14}$ I do not think that Schauer would have agreed in her interpretation of his article. He has written quite critically about slippery slope arguments elsewhere. See Schauer 1985.

${ }^{15}$ It is unclear whether she endorses or rejects the slippery slope argument when it comes to banning Holocaust denial. At this point she is either unclear or inconsistent with her earlier view (McKinnon 2006: 163).

${ }^{16} \mathrm{I}$ know that this is a famous argument from the defenders of slavery previous to the Civil War in the USA. However, I do not think that the two cases are similar, although much more could be said about this point.

\section{References}

Austgulen, M.H. and Stø, E. (2012). Klimaskepsis i Norge. Retrieved from http://www.sifo.no/files/file78113_presentasjon_offentlig_9-mai.pdf

Andersson, A. (2012, May 9). Flere klimaskeptikere. Bergens Tidene. Retrieved from http://www.bt.no/nyheter/lokalt/Flere-klimaskeptikere-2700710.html

Binder, A., Scheufele, D. A., Brossard, D. and Gunther, A. C. (2011). Interpersonal amplification of risk? Citizen discussions and their impact on perceptions of risks and benefits of a biological research facility. Risk Analysis 1: 324-334. http://dx.doi.org/10.1111/j.1539-6924.2010.01516.x

Boykoff, M. and Boykoff J. (2004). Balance as bias: global warming and the US prestige press, Global Environmental Change 14, 125-136. http://dx.doi.org/ 10.1016/j.gloenvcha.2003.10.001

Boykoff, M. (2011). Who speaks for the climate? Making sense of media reporting on climate change. Cambridge: Cambridge University Press. http://dx.doi.org/ $10.1017 / \mathrm{CBO} 9780511978586$

Broome, J. (2012). Climate matters. New York: W.W. Norton \& Company, Inc.

Dimiero, B. (2010) FOXLEAKS: Fox boss ordered staff to cast doubt on climate science. Media Matters for America. Retrieved from http://mediamatters.org/blog /201012150004

Dunlap, R. and McCright, A.M. (2011). Organized climate change denial. In Dryzek, Norgaard, Schosberg (Eds.), The Oxford handbook of climate change 
and society. Oxford: Oxford University Press, 144-160. http://dx.doi.org/ 10.1093/oxfordhb/9780199566600.003.0010

Dunlap, R. and McCright A.M. (2013). The Climate Change Denial Campaign. Scholar's Strategy Network. http://www.scholarsstrategynetwork.org/brief/ climate-change-denial-campaign

Gardiner, S. (2011). A perfect moral storm. The ethical tragedy of climate change. Oxford: Oxford University Press. http://dx.doi.org/10.1093/acprof:oso/ 9780195379440.001.0001

Gelbspan, R. (1998). The heat is on: the climate crisis, the cover- up, the prescription. Boston, MA: Perseus Press.

Greenpeace. (2013). Dealing in Doubt: The climate denial machine vs climate science. A brief history of attacks on climate science, climate scientists and the IPCC. Retreived from http://www.climateaccess.org/sites/default/files/ Greenpeace_Dealing in Doubt.pdf.

Habermas, J. (2006). Does democracy still enjoy an epistemic dimension? Communication Theory 16: 411-426. http://dx.doi.org/10.1111/j.1468-2885. 2006. 00280.x

Hulme, M. (2009). Why we disagree about climate change. Understanding controversy, inaction and opportunity. Cambridge: Cambridge University Press. http://dx.doi.org/10.1017/CBO9780511841200

Kahan, D. M., Wittlin, M., Peters, E., Slovic, P., Ouellette, L. L., Braman, D., Mandel, G. (2011). The tragedy of the risk-perception commons: Culture conflict, rationality conflict, and climate change. Culture Cognition Project. Working Paper No. 89. Retrieved from http://papers.ssrn.com/sol3/papers.cfm? abstract_id=1871503. http://dx.doi.org/10.2139/ssrn.1871503

Kahan, D. M., Peters, E., Wittlin, M., Slovic, P., Ouellette, L. L., Braman, D., \& Mandel, G. (2012). The polarizing impact of science literacy and numeracy on perceived climate change risks. Nature Climate Change, 2(10): 732-735. http://dx.doi.org/10.1038/nclimate1547

Kitcher, P. (2011). Science in a Democratic Society. New York: Prometheus Books.

McKinnon, C. (2006). Toleration. A Critical Introduction. London: Routledge. http://dx.doi.org/10.4324/9780203300640

Mill, J. S. [1859] (2003). On Liberty. New Haven: Yale University Press

Monbiot, G. (2006). Heat. How to stop the planet from burning. Cambridge MA: South End Press.

North Carolina State University. (2010, November 5). More talk, less agreement: Risk discussion can hurt consensus-building on science/technology. ScienceDaily. Retrieved from http://www.sciencedaily.com/releases/2010/ 11/101104111024.htm

NRK (2010, March 14). Halvparten mener klimatrusselen er overdrevet. NRK.NO. Retrieved from http://www.nrk.no/norge/en-av-to-tviler-pa-klimatrusselen-1.70 38438.

Oreskes, N. and Conway, E.M. (2010). Merchants of Doubt. How a Handful of Scientists Obscured the Truth on Issues from Tobacco Smoke to Global Warming. New York: Bloomsbury Press. 
Painter, J. (2011). Poles Apart. The international reporting of climate scepticism. Oxford: RISJ. Available at https://reutersinstitute.politics.ox.ac.uk/sites/default/ files/Poles Apart the international reporting of climate scepticism.pdf

Parfit, D. (2010). Energy Policy and the Further Future: The identity problem. In Gardiner, Caney, Jamieson, Shue (Eds.), Climate Ethics: Essential Readings. Oxford; Oxford University Press, 112-121.

Scanlon, T.M (2003a). Freedom of expression and the categories of expression. In Scanlon The Difficulty of Tolerance. Essays in Political philosophy. Cambridge: Cambridge University Press, 84-112. http://dx.doi.org/10.1017/CBO97805 11615153.006

Scanlon, T.M (2003b). Content regulation reconsidered. In Scanlon: The Difficulty of Tolerance. Essays in political philosophy. Cambridge: Cambridge University Press, 151-168. http://dx.doi.org/10.1017/CBO9780511615153.009

Frederick, S. (1989). The second-best First Amendment. William and Mary Law Review vol.31, no. 1, 1-22.

Frederick S. (1985). Slippery slopes. Harvard Law Review 99 (2): 361-383. http://dx.doi.org/10.2307/1341127

Shermer, M. (2010). I am a sceptic, but I'm not a denier. New Scientist 15 May.

Saloojee, Y. and Dagli, E. (2000). Tobacco industry tactics for resisting policy on health. Bulletin of the World Health Organization, 2000, 78 (7)

TNS Gallup. (2011). Klimabarometeret 2011. Retrieved from http://www.tnsgallup.no/?aid $=9075372 \&$ archive $=$ true $\&$ nid $=9100587$. Archive copy available at http://archive-no.com/page/79455/2012-07-07/http://www.tnsgallup.no/?did=9100587

Washington, H. and Cook, J. (2011). Climate change denial: Heads in the sand. Hoboken: Taylor \& Francis. 